\title{
Changes in Body Composition After 6 Months of Training in Pubertal Swimmers
}

\author{
Cambios en la Composición Corporal Después de \\ 6 Meses de Entrenamiento en Nadadores Púberes
}

Mário A. Rodrigues-Ferreira",***; António M. VencesBrito"*; João Mendes,",**; Renato Fernandes ${ }^{* * *}$ \& Catarina Fernando

RODRIGUES-FERREIRA, M. A.; VENCESBRITO, A. M.; MENDES, J.; FERNANDES, R. \& FERNANDO, C. Changes in body composition after 6 months of training in pubertal swimmers. Int. J. Morphol., 33(1):350-354, 2015.

SUMMARY: This study assessed the differences in body composition after 6 months of training in pubertal boys and girl swimmers and in pubertal boys and girls without sport practice. The swimming group was composed of 20 pubertal swimmers: 10 boys (SB) (age: $13.5 \pm 1.5$ years; Tanner stage: $3.6 \pm 0.5$ ) and 10 girls (SG) (age: $11.3 \pm 0.7$ years; Tanner stage: $3.4 \pm 0.5$ ), with an average training experience of $4 \pm 1.3$ and $3 \pm 0.5$ years, respectively. The control group was composed of 20 pubertal participants without sport practice: 10 boys (CB) (age: 13.6 \pm 1.2 years; Tanner stage: $3.5 \pm 0.5$ ) and 10 girls (CG) (age: $11.2 \pm 0.8$ years; Tanner stage: $3.5 \pm 0.5$ ). The following anthropometric measurements were carried out in two assessment periods (pre- and post-test): height, weight and skinfold thickness (biceps, triceps, subscapular and suprailiac). The sum of 4 skinfolds allowed calculating the percentage of fat mass according to sex and maturational status equations. The Pared-Samples T test was used to analyze the differences between the two assessment periods (preand post-test). Between the pre- and post-test, the percentage of fat mass was significantly lower in $\mathrm{SB}(\mathrm{p}=0.014)$ and $\mathrm{SG}(\mathrm{p}=0.016)$, and significantly higher in CG ( $\mathrm{p}=0.007)$. In conclusion, a decrease in the percentage of fat mass was observed in pubertal boys and girls swimmers after 6 months of training compared with the control group, and those results seem to be associated with the swimming training, specifically the high training volume.

KEY WORDS: Morphology; Body composition; Pubertal athletes; Swimming.

\section{INTRODUCTION}

The external morphology refers to the study of bones, muscles and adipose tissue during growth and development (Fragoso \& Vieira, 2011), where the body composition is generally expressed as the percentage of fat mass and fat-free mass considering the two compartments model (Claessens et al., 2000; Malina, 2007; Lohman et al., 2008; Malin \& Geithner, 2011; Slater et al., 2013). The regular monitoring of body composition in sports is an important indicator of the health and physical development of the adolescent athletes (Lohman et al.; Slater et al.), namely detecting eating disorders, overtraining, illness or to relate body composition to performance. In addition, the evaluation of external morphology is inherent in the identification, selection and development of young talent athletes (Malina \& Beunen, 2008), for example, the identification of essential elements of the body composition for the demands of the sport (Rossi et al., 2014). Currently there are available several methods for the assessment of body composition in adolescent athletes (Claessens et al.; Malina et al., 2004; Malina, 2007; Malina \& Geithner; Lohman et al.; Slater et al.), however due to the low time required, low cost and practical aspects, the anthropometry is one of the most used methods for the evaluation of the external morphology of various populations of adolescents, including young athletes (Claessens et al.; Malina, 2007; Lohman et al.; Slater et al.). In young athletes, low levels of fat are generally observed (Malina, 2009; Malina \& Geithner, 2011), including lower adiposity measured through skinfolds, lower body mass index (BMI) and lower percentage of fat mass (Strong et al., 2005), influenced by the type of sport practiced (Malina \& Geithner; Slater $e t$ $a l$.). There is a scarcity of studies that evaluate the changes in body composition associated with training in young boy and girl athletes. Thus, the aim of the study was to analyze the differences in body composition after 6 months of training in pubertal boy and girl swimmers.

\footnotetext{
* University of Madeira, Funchal, Portugal.

** Sport Sciences School of Rio Maior, Polytechnic Institute of Santarém, Rio Maior, Portugal.
} 


\section{MATERIAL AND METHOD}

Participants. The sample consisted in 40 young participants divided into two groups. The swimming group was composed by 20 pubertal swimmers, of which 10 boys (SB) (age: $13.5 \pm 1.5$ years; Tanner stage: $3.6 \pm 0.5$ ) and 10 girls (SG) (age: $11.3 \pm 0.7$ years; Tanner stage: $3.4 \pm 0.5$ ) with an average of training experience of $4 \pm 1.3$ years and $3 \pm 0.5$ years, respectively. The control group was composed of 20 pubertal participants without sport practice, 10 boys (CB) (age: $13.6 \pm 1.2$ years; Tanner stage: $3.5 \pm 0.5$ ) and 10 girls (CG) (age: $11.2 \pm 0.8$ years; Tanner stage: $3.5 \pm 0.5$ ). All participants volunteered and signed an informed assent, while the parents or guardians signed an informed consent (Winter \& Cobb, 2008), for participation in the study, after being informed about the objectives and procedures involved. The study was approved by the Scientific Committee of the University of Madeira and the Sport Sciences School of Rio Maior, Polytechnic Institute of Santarém.

Procedures. The data collection was performed at the Laboratory for Research in Sports of the Sport Sciences School of Rio Maior - Polytechnic Institute of Santarém. The study was a quasi-experimental design with nonequivalent groups. The time between the two assessment periods was similar in both groups, namely $181 \pm 11$ days in the swimming group and $178 \pm 8$ days in the control group. The pubertal boy and girl swimmers had $6 \pm 1$ and $5 \pm 1$ training session per week, respectively. The weekly training volume was $24800 \pm 9150$ and $14800 \pm 3650$ meters for boy and girl swimmers, respectively, with approximately $95 \%$ of aerobic training and $5 \%$ of anaerobic training. The protocols proposed by the International Society for the Advancement of Kinanthropometry (ISAK) were used for the anthropometric evaluation (Fragoso \& Vieira; Slater et al.). The assessment of biological maturation of the participants, through self-rating (Baxter-Jones et al., 2005; Baxter-Jones \& Sherar, 2007; Malina \& Beunen), was done based on the developmental stages of pubic hair described by Tanner (1962), using the schematic illustrations and descriptive criteria for each stage (adapted from Malina et al.).

Anthropometrical Measurements. In the two assessment periods, the participants were evaluated at the same time of the day and all measurements were performed by the same researcher (Hume \& Marfell-Jones, 2008; Slater et al.), with experience in the anthropometric evaluation of young people. The variables were evaluated three times in a rotation system and all measurements did not exceed the tolerance limit set by ISAK (Fragoso \& Vieira). Special attention was given to the preparation of the material and environmental conditions in order to promote a calm and reserved space to the measurements of the young participants (Eston et al., 2009). The anthropometric measurements were as follows: height (stadiometer Seca, Hamburg, Germany), weight (Tanita BC558 Tetrapolar, Japan) and skinfold thickness (biceps, triceps, subscapular and suprailiac) (Slim Guide, Canada). Skinfold callipers had a constant closing compression of 10 $\mathrm{g} \cdot \mathrm{mm}-2$ throughout the range of measurements (Stewart $e t$ al., 2011). The percentage of fat mass was calculated through the equations:

Pubertal boys equation: Fat mass $(\%)=18.7 \log 10$ (BIC+TRI+SBS+SIL) -11.91

Pubertal girls equation: Fat mass $(\%)=23.94 \log 10$ (BIC+TRI+SBS+SIL) -18.89

using the sum of 4 skinfolds (biceps, triceps, subscapular and suprailiac) according to sex and maturational status (Deurenberg et al., 1990).

Statistical Analysis. Descriptive data are presented as mean \pm standard deviation. Statistical analysis was performed in the Statistical Package for Social Sciences (SPSS) version 17.0, and the level of significance was set at 5\%. The ShapiroWilks test was used to analyse the normality of the data distribution, while Levene's test was used to analyse the homogeneity of variances. The Pared-Samples T test was used to analyze the differences between the two assessment periods (pre- and post-test).

\section{RESULTS}

Table I presents the morphological characteristics of the participants in the two assessment periods. Between the pre- and post-test, height differed significantly in all the subgroups ( $p<0.001)$, weight differed significantly in the SB and $S G(p=0.005)$ and the CG ( $p=0.005)$, and the BMI differed significantly in the $\mathrm{CG}(\mathrm{p}=0.044)$.

Table II shows the results of the skinfold thickness and the percentage of fat mass in the two assessment periods. The SB presented significantly lower biceps $(\mathrm{p}=0.008)$, triceps $(\mathrm{p}=0.043)$ and suprailiac $(\mathrm{p}=0.013)$ skinfolds. The SG showed significantly lower biceps $(p=0.028)$ and suprailiac $(\mathrm{p}=0.020)$ skinfolds. The CG presented significantly higher biceps $(\mathrm{p}=0.005)$, subscapular $(\mathrm{p}=$ $0.016)$ and suprailiac $(\mathrm{p}=0.005)$ skinfolds. Between the preand post-test, the percentage of fat mass was significantly lower in SB ( $\mathrm{p}=0.014)$ and $\mathrm{SG}(\mathrm{p}=0.016)$, and significantly higher in $C G(p=0.007)$. 
Table I. Morphological characteristics of the participants in the two assessment periods.

\begin{tabular}{lccccc}
\hline Variable & Subgroups & Pre & Post & $\boldsymbol{t}$ & $\boldsymbol{p}$ \\
\hline Height $(\mathrm{cm})$ & SB & $166.9 \pm 8.5$ & $170.4 \pm 7.9$ & -10.692 & $<0.001$ \\
& SG & $152.7 \pm 5.4$ & $155.1 \pm 5.1$ & -8.287 & $<0.001$ \\
& CB & $163.6 \pm 6.8$ & $166.3 \pm 6.9$ & -13.294 & $<0.001$ \\
Weight $(\mathrm{kg})$ & CG & $150.0 \pm 6.8$ & $152.2 \pm 6.9$ & -13.531 & $<0.001$ \\
& SB & $56.8 \pm 10.3$ & $59.5 \pm 10.0$ & -3.680 & 0.005 \\
& SG & $46.4 \pm 6.8$ & $48.4 \pm 7.4$ & -3.756 & 0.005 \\
& CB & $67.3 \pm 14.7$ & $68.9 \pm 13.6$ & -2.161 & 0.059 \\
BMI $(\mathrm{kg} \cdot \mathrm{m}-2)$ & CG & $41.1 \pm 7.2$ & $43.2 \pm 7.7$ & -5.509 & $<0.001$ \\
& SB & $20.3 \pm 2.6$ & $20.4 \pm 2.4$ & -0.553 & 0.594 \\
& SG & $19.8 \pm 2.3$ & $20.1 \pm 2.3$ & -0.960 & 0.362 \\
& CB & $25.1 \pm 5.2$ & $24.9 \pm 4.6$ & 0.221 & 0.830 \\
& CG & $18.2 \pm 2.2$ & $18.5 \pm 2.3$ & -2.343 & 0.044 \\
\hline
\end{tabular}

Note. $\mathrm{BMI}=$ body mass index; $\mathrm{cm}=$ centimeter; $\mathrm{kg}=$ kilogram; $\mathrm{m}=$ meter; $\mathrm{SB}=$ boy swimmers; $\mathrm{SG}=$ girl swimmers; $\mathrm{CB}=$ boys without sport practice; $\mathrm{CG}=$ girls without sport practice.

Table II. Skinfold thickness and fat mass (\%) of the participants in the two assessment periods.

\begin{tabular}{lccccc}
\hline Variable & Subgroups & Pre & Post & $\boldsymbol{t}$ & $\boldsymbol{p}$ \\
\hline Biceps $(\mathrm{mm})$ & SB & $6.5 \pm 3.2$ & $4.8 \pm 2.1$ & 3.431 & 0.008 \\
& SG & $8.5 \pm 2.8$ & $7.2 \pm 2.3$ & 2.623 & 0.028 \\
Triceps $(\mathrm{mm})$ & CB & $12.2 \pm 5.6$ & $12.6 \pm 5.7$ & -0.612 & 0.555 \\
& CG & $6.8 \pm 4.2$ & $8.6 \pm 4.5$ & -3.674 & 0.005 \\
& SB & $11.5 \pm 3.9$ & $9.6 \pm 3.4$ & 2.349 & 0.043 \\
& SG & $14.2 \pm 4.1$ & $12.6 \pm 2.9$ & 1.953 & 0.083 \\
Subscapular $(\mathrm{mm})$ & CB & $19.5 \pm 6.4$ & $18.3 \pm 6.7$ & 1.406 & 0.193 \\
& CG & $12.9 \pm 6.0$ & $13.6 \pm 6.2$ & -1.481 & 0.173 \\
& SB & $8.8 \pm 3.8$ & $7.6 \pm 2.5$ & 1.385 & 0.200 \\
Suprailiac $(\mathrm{mm})$ & SG & $10.7 \pm 5.3$ & $8.7 \pm 3.4$ & 2.236 & 0.052 \\
& CB & $19.8 \pm 8.4$ & $19.9 \pm 8.0$ & -0.133 & 0.897 \\
& CG & $8.5 \pm 4.2$ & $10.4 \pm 5.1$ & -2.967 & 0.016 \\
& SB & $10.4 \pm 4.9$ & $7.9 \pm 4.2$ & 3.101 & 0.013 \\
Fat mass $(\%)$ & SG & $13.3 \pm 5.3$ & $10.0 \pm 5.5$ & 2.810 & 0.020 \\
& CB & $23.0 \pm 7.6$ & $21.8 \pm 8.5$ & 0.950 & 0.367 \\
& CG & $9.3 \pm 5.4$ & $11.3 \pm 6.8$ & -3.721 & 0.005 \\
& SB & $16.9 \pm 3.3$ & $15.2 \pm 2.9$ & 3.045 & 0.014 \\
& SG & $20.5 \pm 3.6$ & $18.6 \pm 3.1$ & 2.957 & 0.016 \\
& CB & $22.6 \pm 3.2$ & $22.3 \pm 3.2$ & -0.431 & 0.676 \\
& CG & $17.9 \pm 4.5$ & $19.4 \pm 4.9$ & -3.434 & 0.007 \\
\hline
\end{tabular}

Note. $\mathrm{mm}=$ millimeter; \%= percentage; $\mathrm{SB}=$ boy swimmers; $\mathrm{SG}=$ girl swimmers; $\mathrm{CB}=$ boys without sport practice; $\mathrm{CG}=$ girls without sport practice.

\section{DISCUSSION}

This research presented the body composition before and after 6 months of training in pubertal boys and girls swimmers. The main finding of this study was that the percentage of fat mass was significantly lower in the posttest in SB and SG, and it might be due to the training volume that the pubertal athletes had completed. Those results were consistent with the findings of other authors that observed a lower adiposity and lower percentage of fat mass in young athletes (Strong et al.; Malina, 2009; Malina \& Geithner; Slater et al.). The sport and physical activity are seen as important for long-term benefits in body composition (Janz et al., 2009). One limitation of this study was that we did 
not control effectively the nutritional patterns and that could also affect the body composition. However, the participants reported no great changes in their nutritional during the study.

On the other hand, in the control group the CB showed no changes after the 6 months in the skinfold thickness and percentage of fat mass, however the CG showed a significantly higher percentage of fat mass, suggesting sex differences on growth and maturation of body composition, namely the increases in muscle mass and bone tissue in boys and an increase in adipose tissue in girls, especially during puberty (Malina et al.; Baxter-Jones \& Sherar; Baxter-Jones, 2008; Beunen \& Malina).

With respect to the morphological characteristics, a significantly higher height and weight (except for the CB), has been found in all the subgroups that corroborates the values observed in typical growth curves for height and weight (Malina et al.; Baxter-Jones \& Sherar; Baxter-Jones), and were similar between the swimming and control groups (Beunen \& Malina). The morphological characteristics were similar to other studies of young boys (Schneider \& Meyer, 2005; Wells et al., 2006) and girls (Schneider \& Meyer, 2005; Wells et al., 2006; Erlandson et al., 2008) swimmers.

In conclusion, a decrease in the percentage of fat mass was observed in pubertal boy and girl swimmers after 6 months of training compared with the control group, and those results seem to be associated with the swimming training, specifically the high training volume. A higher percentage of fat mass is commonly inversely correlated with performance, thus is important for the coaches to evaluate the body composition of the young athletes throughout the season. Future studies should evaluate the relationship between morphological variables and the swimming performance.

RODRIGUES-FERREIRA, M. A.; VENCESBRITO, A. M.; MENDES, J.; FERNANDES, R. \& FERNANDO, C. Las modificaciones en la composición corporal después de 6 meses de entrenamiento en nadadores púberes. Int. J. Morphol., 33(1):350-354, 2015.

RESUMEN: Este estudio evaluó las diferencias en la composición corporal después de 6 meses de entrenamiento en niños y niñas púberes nadadores y en los niños y niñas púberes sin la práctica del deporte. El grupo de natación fue compuesta por 20 nadadores púberes: 10 niños (SB) (edad: 13,5 $\pm 1,5$ años; Tanner etapa: 3,6 $\pm 0,5$ ) y 10 niñas (SG) (edad: 11,3 $\pm 0,7$ años; estadio de Tanner: 3,4 $\pm 0,5$ ), con una media de experiencia de entrenamiento de $4 \pm 1,3$ y $3 \pm 0,5$ años, respectivamente. El grupo de control estaba compuesto por 20

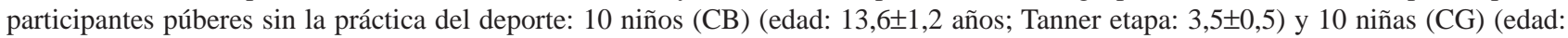

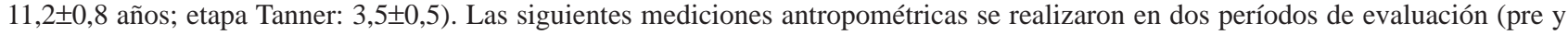
post-prueba): altura, peso y pliegues cutáneos (bíceps, tríceps, subescapular y suprailíaco). La suma de 4 pliegues cutáneos permitió calcular el porcentaje de masa grasa según las ecuaciones apropiado al estado de maduración e sexo. Se utilizó la técnica estadística T para muestras pareadas para analizar las diferencias entre los dos períodos de evaluación (pre y post- prueba). Entre la pre y post- prueba, el porcentaje de masa grasa fue significativamente menor en el SB ( $\mathrm{p}=0,014)$ y SG ( $\mathrm{p}=\mathrm{M} 0,016)$, y significativamente mayor en CG ( $\mathrm{p}=$ 0,007). En conclusión, se observó una disminución en el porcentaje de masa grasa en los niños y niñas púberes nadadores después de 6 meses de entrenamiento en comparación con el grupo control, y esos resultados parecen estar asociados con el entrenamiento de natación, en especial el alto volumen de entrenamiento.

PALABRAS CLAVE: Morfología; Composición corporal; Atletas en la pubertad; Natación.

\section{REFERENCES}

Baxter-Jones, A. D. G. Growth and Maturation. In: Armstrong, N. \& Van Mechelen, W. (Eds.). Paediatric Exercise Science and Medicine. 2nd ed. Oxford, Oxford University Press, 2008. pp.157-68.

Baxter-Jones, A. D. G. \& Sherar, L. B. Growth and Maturation. In: Armstrong, N. (Ed.). Paediatric Exercise Physiology: Advances in Sport and Exercise Science Series. Philadelphia, Churchill Livingstone Elsevier, 2007. pp.1-26.

Baxter-Jones, A. D. G.; Eisenmann, J. C. \& Sherar, L. B. Controlling for maturation in pediatric exercise science. Pediatr. Exerc. Sci., 17(1):18-30, 2005.
Beunen, G. \& Malina, R. M. Growth and Biologic Maturation: Relevance to Athletic Performance. In: Hebestreit, H. \& BarOr, O. (Eds.). The Young Athlete. Oxford, Blackwell Publishing, 2008. pp.3-17.

Claessens, A. L.; Beunen, G. \& Malina, R. M. Anthropometry, Physique, Body Composition and Maturity. In: Armstrong, N. \& Van Mechelen, W. (Eds.). Paediatric Exercise Science and Medicine. 2nd ed. Oxford, Oxford University Press, 2000. pp.23-36.

Deurenberg, P.; Pieters, J. J. \& Hautvast, J. G. The assessment of the body fat percentage by skinfold thickness measurements 
in childhood and young adolescence. Br. J. Nutr., 63(2):293303, 1990.

Erlandson, M. C.; Sherar, L. B.; Mirwald, R. L.; Maffulli, N. \& Baxter-Jones, A. D. G. Growth and maturation of adolescent female gymnasts, swimmers, and tennis players. Med. Sci. Sports Exerc., 40(1):34-42, 2008.

Eston, R.; Hawes, M.; Martin, A. \& Reilly, T. Human Body Composition. In: Eston, R. \& Reilly, T. (Eds.). Kinanthropometry and Exercise Physiology Laboratory Manual: Tests, Procedures and Data. 3rd ed. Oxon, Routledge, 2009. pp.3-53.

Fragoso, I. \& Vieira, F. Cinantropometria - Curso Prático. Cruz Quebrada, F. M. H., 2011.

Hume, P. \& Marfell-Jones, M. The importance of accurate site location for skinfold measurement. J. Sports Sci., 26(12):133340, 2008.

Janz, K. F.; Kwon, S.; Letuchy, E. M.; Eichenberger Gilmore, J. M.; Burns, T. L.; Torner, J. C.; Willing, M. C. \& Levy, S. M. Sustained effect of early physical activity on body fat mass in older children. Am. J. Prev. Med., 37(1):35-40, 2009.

Lohman, T. G.; Going, S. B. \& Herrin, B. R. Body Composition Assessment in the Young Athlete. In: Hebestreit, H. \& Bar-Or, O. (Eds.). The Young Athlete. Oxford, Blackwell Publishing, 2008. pp.415-29.

Malina, R. M. Body composition in athletes: assessment and estimated fatness. Clin. Sports Med., 26(1):37-68, 2007.

Malina, R. M. Children and adolescents in the sport culture: The overwhelming majority to the select few. J. Exerc. Sci. Fit., 7(Suppl.):S1-10, 2009.

Malina, R. M. \& Beunen, G. Growth and Maturation: Methods of Monitoring. In: Hebestreit, H. \& Bar-Or, O. (Eds.). The Young Athlete. Oxford, Blackwell Publishing, 2008. pp.430-42.

Malina, R. M. \& Geithner, C. A. Body composition of young athletes. Am. J. Lifestyle Med., 5(3):262-78, 2011.

Malina, R. M.; Bouchard, C. \& Bar-Or, O. Growth, Maturation and Physical Activity. 2nd ed. Champaign, Human Kinetics, 2004.

Rossi, F. E.; Ricci-Vitor, A. L.; Sabino, J. P.; Vanderlei, L. C. \& Freitas, I. F. Jr. Autonomic modulation and its relation with body composition in swimmers. J. Strength Cond. Res., 28(7):2047-53, 2014.

Schneider, P. \& Meyer, F. Anthropometric and muscle strength evaluation in prepubescent and pubescent swimmer boys and girls. Rev. Bras. Med. Esporte, 11(4):200-3, 2005.
Slater, G.; Woolford, S. M. \& Marfell-Jones, M. J. Assessment of Physique. In: Tanner, R. K. \& Gore, C. J. (Eds.). Physiological tests for elite athletes. 2nd ed. Champaign, Human Kinetics, 2013. pp.167-98.

Stewart, A. D.; Marfell-Jones, M. J.; Olds, T. \& De Ridder, J. H. International standards for anthropometric assessment. Lower Hutt, International Society for the Advancement of Kinanthropometry (ISAK), 2011.

Strong, W. B.; Malina, R. M.; Blimkie, C. J.; Daniels, S. R.; Dishman, R. K.; Gutin, B.; Hergenroeder, A. C.; Must, A.; Nixon, P. A.; Pivarnik, J. M.; Rowland, T.; Trost, S. \& Trudeau, F. Evidence based physical activity for school-age youth. $J$. Pediatr., 146(6):732-7, 2005.

Tanner, J. M. Growth and Adolescence. Oxford, Blackwell Scientific Publications, 1962.

Wells, G. D.; Schneiderman-Walker, J. \& Plyley, M. Normal physiological characteristics of elite swimmers. Pediatr. Exerc. Sci., 18(1):30-52, 2006.

Winter, E. M. \& Cobb, M. Ethics in Paediatric Research: Principles and Processes. In: Armstrong, N. \& Van Mechelen, W. (Eds.). Paediatric Exercise Science and Medicine. 2nd ed. Oxford, Oxford University Press, 2008. pp.3-12.

Correspondence to:

Mário A. Rodrigues-Ferreira

Escola Superior de Desporto de Rio Maior

Av. Dr. Mário Soares, 2040-413

Rio Maior

PORTUGAL

Email: marioarferreira@esdrm.ipsantarem.pt

Received: $27-10-2014$

Accepted: 07-01-2015 